\title{
Bioanalytical HPLC method development for simultaneous determination of valsartan and co-administered clopidogrel bisulfate and fenofibrate in stroke prevention in raw materials, spiked human plasma and tablets
}

\author{
Gamal H. Ragab and Eman A. Bahgat ${ }^{\bowtie}$ \\ Pharmaceutical Analytical Chemistry Department, Zagazig University, Faculty of Pharmacy, Zagazig 44519, Egypt
}

\section{Article info}

\section{Article history:}

Received: $29^{\text {th }}$ June 2018

Accepted: $6^{\text {th }}$ September 2018

\section{Keywords:}

Valsartan

Clopidogrel bisulfate

Fenofibrate

Plasma

RP-HPLC method

Tablets

\begin{abstract}
This study reports about simple, robust and reproducible method for simultaneous bioanalytical determination of Valsartan (VAL) and co-administered Clopidogrel bisulfate (CGB) and Fenofibrate (FEN) in raw materials, spiked human plasma and tablets using isocratic RP-HPLC method. The chromatographic separation is carried out using isocratic binary mobile phase consisting of $80 \mathrm{mM}$ phosphate buffer $\mathrm{pH} 3$ : Acetonitrile (30: $70 \% ; v / v)$ at the flow rate of $1.1 \mathrm{~mL} / \mathrm{min}$ and $33{ }^{\circ} \mathrm{C}$. A Diode array detector at wavelength $214 \mathrm{~nm}$ was used. Retention times for VAL, CGB and FEN were 3.1, 5.1 and $6.4 \mathrm{~min}$, respectively. The calibration curves obtained were linear over the concentration ranges of $2.5-100 \mu \mathrm{g} / \mathrm{mL}$ for both VAL and CGB and $5-100 \mu \mathrm{g} / \mathrm{mL}$ for FEN. The mean extraction recoveries of VAL, CGB and FEN from spiked plasma were $75.38 \pm 1.34 \%, 89.91 \pm 2.17 \%$ and $96.92 \pm 6.02 \%$, respectively. The limits of detection and quantification were $0.86,0.67,1.11 \mu \mathrm{g} / \mathrm{mL}$ and $2.60,2.03,3.36 \mu \mathrm{g} / \mathrm{mL}$ for VAL, CGB and FEN, respectively. The method was applied to the analysis of these drugs in spiked human plasma and in tablets as they are commonly used as a combination for prevention of stroke. Results obtained show good accuracy, precision and acceptable recoveries from plasma samples.
\end{abstract}

(C) University of SS. Cyril and Methodius in Trnava

\section{Introduction}

Valsartan is an angiotensin-II receptor antagonist, used in treatment of hypertension. It is also used for patients with heart failure who are unable to tolerate ACE inhibitors (Sweetman 2009).

Clopidogrel bisulphate is a thienopyridine antiplatelet drug, used in the treatment of thromboembolic disorders (Sweetman 2009). Clopidogrel bisulphate is official, have been determined in BP (The British Pharmacopoeia 2017) by titration with $0.1 \mathrm{M}$ sodium hydroxide then the end-point determined potentiometrically and in USP (The United States Pharmacopoeia 2007) by HPLC method.
Fenofibrate is fibric acid derivative, used for regulating the lipids of plasma and in the treatment of hyper-lipoprotein-aemias (Sweetman 2009).

Literatures reveal different methods for determination of all the three drugs in combinations with other drugs. Valsartan have been determined by using RP-HPLC methods in combination with hydrochlorothiazide in tablets (Tian et al. 2008) and also with amlodipine and hydrochlorothiazide in tablets and spiked human plasma (El-Gizawy et al. 2012). Clopidogrel-bisulfate have been determined by using RP-HPLC methods in combination with aspirin in tablets (Shrivastava et al. 2008), aspirin and atorvastatin calcium in capsules (Londhe et al. 2011) and with 
pantoprazole in rat plasma (Gurupadayya et al. 2014). Fenofibrate have been determined by using RP-HPLC methods in combination with atorvastatin-calcium in tablet dosage forms (Jain et al. 2008) and in combination with atorvastatin and ezetimibe in commercial formulation (Sahu et al. 2016). Also a validated stability indicating RP-HPLC method is used for simultaneous determination of Fenofibrate with atorvastatin and folic acid in bulk and pharmaceutical dosage form have been reported (Khaleel and Abdul Rahaman 2016).

Modern studies state that stroke prevention is the greatest opportunity for decreasing stroke occurrence (Kernan et al. 2014). There had been a significant decrease in stroke occurrence and mortality in several nations around the world over the last decade (Ovbiagele 2011; Hall et al. 2012; Rosengren et al. 2013; Wang et al. 2013). This development in decreasing stroke incidence is mainly due to the better treatment of risk factors for stroke (Gu et al. 2012; Lackland et al. 2014). The systematic combination of secondary prevention drugs is one of the proposed strategies for stroke prevention. For Secondary prevention of stroke, there were 3 possible recommended medication classes: antihypertensive (renin-angiotensin system modulator, $\beta$-blocker, calcium antagonist and diuretic), antithrombotic (antiplatelet or/and anticoagulation), and lipid modifier therapy (i.e., ezetimibe, statin, Fenofibrate and niacin).

In this study, we introduce a simple, robust and precise HPLC method for simultaneous determination of a very effective combination of drugs that are used for secondary prevention of stroke which is Valsartan as antihypertensive, Clopidogrel bisulfate as antiplatelet and Fenofibrate as lipid modifier. There is no reported method for simultaneous determination of the three drugs either in spiked human plasma or in tablets. So, the developed method has been created to determine these drug combinations in both spiked human plasma and in tablets dosage form.

\section{Experimental}

\section{Apparatus}

All separations were achieved on an Agilent
Technologies 1200 series chromatographic apparatus with autosampler injector and $100 \mu \mathrm{L}$ volume injection loop. UV lamp (Germany) and G1315D photodiode array detector (DAD) connected to HP computer loaded with Agilent Chemstation software were used for analytes detection. Chromatograms were recorded on Agilent integrator. Mobile phase was filtered using $0.45 \mu \mathrm{m}$ membrane filter (Millipore, Ireland), degassed using Agilent G1322A vacuum degasser with G1354A isocratic quaternary pump and solvent cabinets.

Thermo Hypersil $(250 \mathrm{~mm} \times 4.6 \mathrm{~mm}$ I.D, $5 \mu \mathrm{m}$ particle size column) was used for the analysis. For $\mathrm{pH}$ adjustment a digital analyzer $\mathrm{pH}$ meter equipped with glass electrode (Hanna, made in Europe, Romania) was used. Ultra-sound sonicator (Raypa, Spain) and also centrifuge (HermLe Labortechnik GmbH, Germany) were used.

\section{Reagents and materials}

Acetonitrile, methanol and water were of HPLC grade (Fisher Scientific, UK), orthophosphoric acid (Fisher Chemical ${ }^{\circledR}$ Laboratory Reagent Grade) and potassium dihydrogen orthophosphate (Fisher Scientific, Fair Lawn, New Jersey).

\section{Samples}

Valsartan was obtained from EIPICO (Egyptian International Pharmaceutical Industry Company), Egypt while Clopidogrel bisulfate and Fenofibrate were obtained from SIGMA pharmaceutical industries, Egypt. All samples should be stored in dry place, away from sunlight and moisture. The human plasma was received from Peoples Hospital, El-Ahrar, Zagazig, Egypt. Plasma samples were frozen immediately at $-20{ }^{\circ} \mathrm{C}$ until assayed.

\section{Pharmaceutical dosage forms}

Tareg® tablets contain $40 \mathrm{mg}$ Valsartan per tablet (product of Novartis Pharm S.A.E. Cairo, under license from: Novartis, USA). Clopex ${ }^{\circledR}$ tablets contain $75 \mathrm{mg}$ Clopidogrel bisulfate per tablet (product of Marcyrl Pharmaceutical IndustriesEgypt) and lipanthyl supra ${ }^{\circledR}$ tablets contain $160 \mathrm{mg}$ 
Fenofibrate (Product of Mina Pharm for Pharmaceuticals \& Chemical Industries-Egypt).

\section{Standard solutions}

Stock standard solutions ( $1 \mathrm{mg} / \mathrm{mL})$ of VAL, CGB and FEN were prepared by dissolving $25 \mathrm{mg}$ of each drug in $25 \mathrm{~mL}$ volumetric flasks in methanol, stored in the refrigerator at $4{ }^{\circ} \mathrm{C}$. These stock standard solutions were stable for one week. Working solutions of VAL, CGB and FEN $(100 \mu \mathrm{g} / \mathrm{mL})$ were prepared, daily by suitable dilution of the stock solutions with methanol, respectively. Different aliquots of working solutions were transferred and diluted in $10 \mathrm{~mL}$ volumetric flasks with methanol to reach the concentration ranges of $2.5-100 \mu \mathrm{g} / \mathrm{mL}$ for $\mathrm{VAL}$ and CGB and $5-100 \mu \mathrm{g} / \mathrm{mL}$ for FEN.

\section{Chromatographic conditions for general procedures}

Analysis process was carried out at ambient temperature using Agilent Thermo Hypersil $(250 \mathrm{~mm} \times 4.6 \mathrm{~mm}$ I.D, $5 \mu \mathrm{m}$ particle size column $)$ and the mobile phase was an isocratic mixture of acetonitrile and $80 \mathrm{mM}$ potassium dihydrogen orthophosphate buffer ( $\mathrm{pH}=3 \pm 0.2$ adjusted using orthophosphoric acid) in a ratio of $(70: 30 ; v / v)$. The analysis was done at a flow rate $1.1 \mathrm{~mL} / \mathrm{min}$ and using Diode array detector at wave length $214 \mathrm{~nm}$ with injection volume $10 \mu \mathrm{L}$. The mobile phase was filtered by passing through a $0.45 \mu \mathrm{m}$ Millipore membrane filter type Hawp.

The working standard solutions were prepared by dilution of the stock standard solution with methanol to reach the concentration ranges cited above. Triplicate $10 \mu \mathrm{L}$ injections were made for each concentration and chromatographed under the optimized conditions described above. The calibration graph was constructed by plotting peak area of each concentration against the corresponding concentration.

\section{Preparation of spiked serum sample}

Prior to the extraction process, drug free plasma samples were removed from the deep freezer and were allowed to thaw. To a constant volume of human plasma $(0.2 \mathrm{~mL}), 0.5 \mathrm{~mL}$ of each standard solution was added into $5 \mathrm{~mL}$ tapered bottom centrifuge tube, and the volume was made up to $4 \mathrm{~mL}$ by a adding $3.3 \mathrm{~mL}$ of a mixture of (acetonitrile: methanol, 1:1) to reach the final concentrations of the drugs in the spiked human plasma samples. The mixture was mixed well, standing for $5 \mathrm{~min}$ at room temperature, finally was centrifuged at $5,000 \mathrm{r} / \mathrm{min}$ for $20 \mathrm{~min}$. To another clean tube, the upper layer was transferred and then filtered through a $0.45 \mu \mathrm{m}$ Millipore syringe filter. $10 \mu \mathrm{L}$ of the clear supernatant was directly injected into the liquid chromatographic system for analysis.

\section{Preparation of pharmaceutical dosage sample}

Ten tablets of the cited drugs were weighed, finely powdered then amount equivalent to $25 \mathrm{mg}$ of each drug was accurately transferred into a $25 \mathrm{~mL}$ volumetric flask, dissolved in methanol and the flask was sonicated for $30 \mathrm{~min}$, the volume was completed to the mark with methanol. The solution was filtered through a $0.45 \mu \mathrm{m}$ membrane filter before injection into the column. The procedures were completed as mentioned above and the concentrations of the three drugs were obtained from the computed regression equations.

\section{Method validation}

The proposed method was validated according to $\mathrm{ICH}$ guidelines (International Conference on Harmonization 2005). It was validated for the parameters as linearity, limit of detection (LOD), limit of quantitation (LOQ), precision, specificity and accuracy.

\section{Linearity, detection and quantitation limits}

Calibration curves were obtained by the analysis of different preparations of one sample of each of the cited drugs and then, it was constructed by plotting the values of peak areas against concentrations of the cited drugs. The limits of detection (LOD) and limits of quantitation (LOQ) were determined in accordance with $\mathrm{ICH}$ recommendation by the use of standard deviation of the response and the slope of the calibration 
curve.

\section{Accuracy}

Accuracy of the measurements of the suggested method was determined using the calibration curves of the three drugs. It was determined by analysis of seven preparations of one sample for all the studied drugs.

\section{Precision}

Intra-day precision was determined for the cited drugs through replicate analysis of two concentrations (10 and $100 \mu \mathrm{g} / \mathrm{mL})$, three successive times.

Inter-day precision was determined through replicate analysis of two concentrations of the cited drugs on three successive days.

\section{Specificity}

The specificity of the proposed method was determined by comparing the chromatogram of the cited drugs in their pure form with the chromatogram obtained when the cited drugs extracted from spiked human plasma samples.

\section{Robustness}

The robustness of the proposed method was evaluated by the constancy of the peak area and the retention time upon deliberate minor variations in the method parameters; these parameters included the flow rate $(1.09,1.1$ and $1.11 \mathrm{~mL} / \mathrm{min})$ and mobile phase ratio (30.5, 30 and 29.5 of phosphate buffer $\mathrm{pH} 3$ ).

\section{Analytical applications}

The validity of the proposed method was evaluated by their application to the determination of the cited drugs in raw material, spiked human plasma and in their separate tablets dosage forms. A statistical comparison of the results obtained by the proposed and the reported methods (Gupta et al. 2010a, The British Pharmacopoeia 2017 and Gupta et al. 2010b) was done.

\section{Results and Discussion}

\section{Method development}

Different chromatographic conditions (organic solvent ratio, flow rate, and $\mathrm{pH}$ ) affecting the chromatographic separation of VAL, CGB and FEN were carefully studied in order to recognize the most suitable chromatographic system, separate the three drugs from each other with very good resolution and to obtain sharp and symmetrical peaks and retention time in between 2 and $8 \mathrm{~min}$.

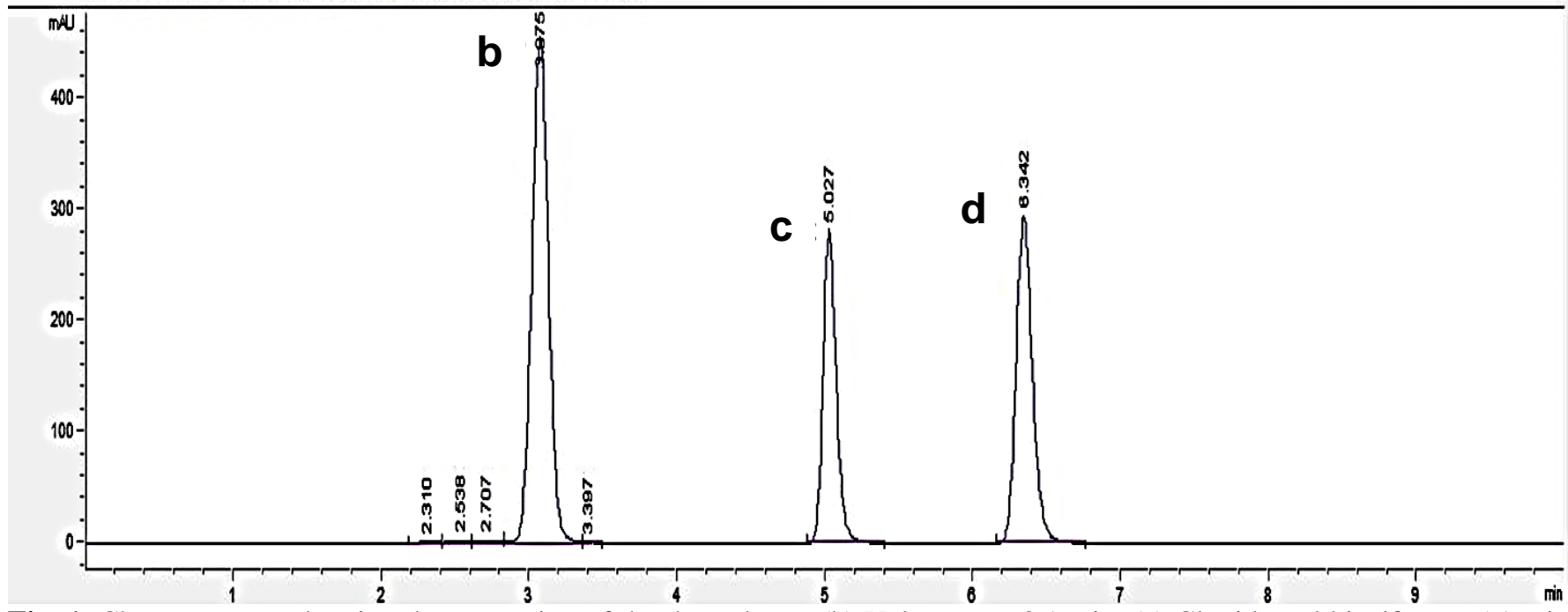

Fig. 1. Chromatogram showing the separation of the three drugs: (b) Valsartan at 3.1 min, (c) Clopidogrel bisulfate at 5.1 min and (d) Fenofibrate at $6.3 \mathrm{~min}$ at concentration level $100 \mu \mathrm{g} / \mathrm{mL}$. 
Table 1. Spectral data for the simultaneous determination of Valsartan, Clopidogrel bisulfate and Fenofibrate by the proposed HPLC method.

\begin{tabular}{llll}
\hline Parameters & Valsartan & Clopidogrel bisulfate & Fenofibrate \\
\hline Linearity range $[\mu \mathrm{g} / \mathrm{mL}]$ & $2.5-100$ & $2.5-100$ & $5-100$ \\
Intercept $(\mathrm{a})$ & 51.89 & -1.51 & -17.08 \\
Slope $(\mathrm{b})$ & 35.73 & 17.56 & 22.83 \\
Correlation coefficient $(\mathrm{r})$ & 0.9998 & 0.9999 & 0.9999 \\
Determination coefficient $(\mathrm{r} 2)$ & 0.9997 & 0.9999 & 0.9999 \\
LOD $[\mu \mathrm{g} / \mathrm{mL}]$ & 0.86 & 0.67 & 1.11 \\
LOQ $[\mu \mathrm{g} / \mathrm{mL}]$ & 2.60 & 2.3 & 3.36 \\
\hline
\end{tabular}

Table 2. Evaluation of the accuracy of the proposed HPLC method.

\begin{tabular}{|c|c|c|c|c|c|c|c|c|c|}
\hline \multicolumn{4}{|c|}{ VAL } & \multicolumn{3}{|c|}{ CGB } & \multicolumn{3}{|c|}{ FEN } \\
\hline Sample & $\begin{array}{c}\text { Taken } \\
{[\mu \mathrm{g} / \mathrm{mL}]}\end{array}$ & $\begin{array}{c}\text { Found } \\
{[\mu \mathrm{g} / \mathrm{mL}]}\end{array}$ & $\begin{array}{c}\text { Recovery } \\
{[\%]}\end{array}$ & $\begin{array}{c}\text { Taken } \\
{[\mu \mathrm{g} / \mathrm{mL}]}\end{array}$ & $\begin{array}{c}\text { Found } \\
{[\mu \mathrm{g} / \mathrm{mL}]}\end{array}$ & $\begin{array}{c}\text { Recovery } \\
{[\%]}\end{array}$ & $\begin{array}{c}\text { Taken } \\
{[\mu \mathrm{g} / \mathrm{mL}]}\end{array}$ & $\begin{array}{c}\text { Found } \\
{[\mu \mathrm{g} / \mathrm{mL}]}\end{array}$ & $\begin{array}{c}\text { Recovery } \\
{[\%]}\end{array}$ \\
\hline 1 & 100.0 & 99.10 & 99.10 & 100.0 & 100.27 & 100.27 & 100 & 100.34 & 100.34 \\
\hline 2 & 70.0 & 71.08 & 101.54 & 70.0 & 69.60 & 99.43 & 50 & 49.36 & 98.73 \\
\hline 3 & 50.0 & 50.30 & 100.60 & 50.0 & 49.69 & 99.39 & 30 & 29.75 & 99.18 \\
\hline 4 & 30.0 & 30.16 & 100.54 & 30.0 & 30.54 & 101.80 & 10 & 10.36 & 103.58 \\
\hline 5 & 10.0 & 9.61 & 96.07 & 10.0 & 9.87 & 98.69 & 5 & 5.17 & 103.46 \\
\hline 6 & 5.0 & 4.79 & 95.79 & 5.0 & 5.30 & 100.58 & & & \\
\hline 7 & 2.5 & 2.47 & 98.65 & 2.5 & 2.48 & 99.11 & & & \\
\hline Mean & & & 98.89 & & & 99.90 & & & 101.06 \\
\hline SD & & & 2.25 & & & 1.06 & & & 2.32 \\
\hline RSD & & & 2.27 & & & 1.06 & & & 2.30 \\
\hline
\end{tabular}

Table 3. Precision and accuracy of intra-day and inter-day analysis.

\begin{tabular}{|c|c|c|c|c|c|c|c|c|c|}
\hline \multirow[b]{2}{*}{ Drug } & \multirow[b]{2}{*}{$\begin{array}{l}\text { Added } \\
{[\mu \mathrm{g} / \mathrm{mL}]}\end{array}$} & \multicolumn{4}{|l|}{ Intra-day } & \multicolumn{4}{|l|}{ Inter-day } \\
\hline & & $\begin{array}{l}\text { Found } \pm \text { SD } \\
{[\mu \mathrm{g} / \mathrm{mL}]}\end{array}$ & $\begin{array}{l}\text { Recovery } \\
{[\%]}\end{array}$ & $\begin{array}{l}\text { RSD } \\
{[\%]}\end{array}$ & $\begin{array}{l}\text { ER } \\
{[\%]}\end{array}$ & $\begin{array}{l}\text { Found } \pm \text { SD } \\
{[\mu \mathrm{g} / \mathrm{mL}]}\end{array}$ & $\begin{array}{l}\text { Recovery } \\
{[\%]}\end{array}$ & $\begin{array}{l}\text { RSD } \\
{[\%]}\end{array}$ & $\begin{array}{l}\text { ER } \\
{[\%]}\end{array}$ \\
\hline \multirow[t]{2}{*}{ VAL } & 10 & $9.85 \pm 2.433$ & 98.49 & 2.470 & -1.50 & $10.30 \pm 2.10$ & 103.03 & 2.037 & 3.03 \\
\hline & 100 & $98.80 \pm 0.292$ & 98.81 & 0.296 & -1.19 & $100.82 \pm 1.72$ & 100.82 & 1.710 & 0.82 \\
\hline \multirow[t]{2}{*}{ CGB } & 10 & $9.81 \pm 0.573$ & 98.11 & 0.584 & -1.89 & $9.84 \pm 0.57$ & 98.11 & 0.584 & -1.89 \\
\hline & 100 & $100.52 \pm 0.242$ & 100.52 & 0.240 & 0.52 & $102.55 \pm 1.67$ & 102.55 & 1.629 & 2.55 \\
\hline \multirow[t]{2}{*}{ FEN } & 10 & $10.42 \pm 0.600$ & 104.19 & 0.576 & 4.19 & $10.42 \pm 0.61$ & 104.19 & 0.576 & 4.19 \\
\hline & 100 & $100.56 \pm 0.191$ & 100.56 & 0.189 & 0.56 & $100.49 \pm 0.15$ & 100.49 & 0.146 & 0.49 \\
\hline
\end{tabular}

\section{Optimization of mobile phase $\mathrm{pH}$}

Different mobile phase $\mathrm{pH}$ values were tried in order to reach the optimum separation conditions. It was found that $\mathrm{pH}$ value below 3 lead to co-elution of the cited drugs. On the other hand, $\mathrm{pH}$ value greater than 3 resulted in increasing the retention times of the three drugs without improving separation. Thus, $\mathrm{pH}$ value of 3 was chosen as optimum $\mathrm{pH}$ for chromatographic separation. The change of $\mathrm{KH}_{2} \mathrm{PO}_{4}$ concentration did not have an influence on the separation process; so concentration of $80 \mathrm{mM}$ of $\mathrm{KH}_{2} \mathrm{PO}_{4}$ was used.

\section{Mobile phase composition}

Using mobile phases containing methanol alone led to separation of the three drugs but with high noise. On the other hand, increasing the concentration of buffer to more than $50 \%$ led to longer retention 


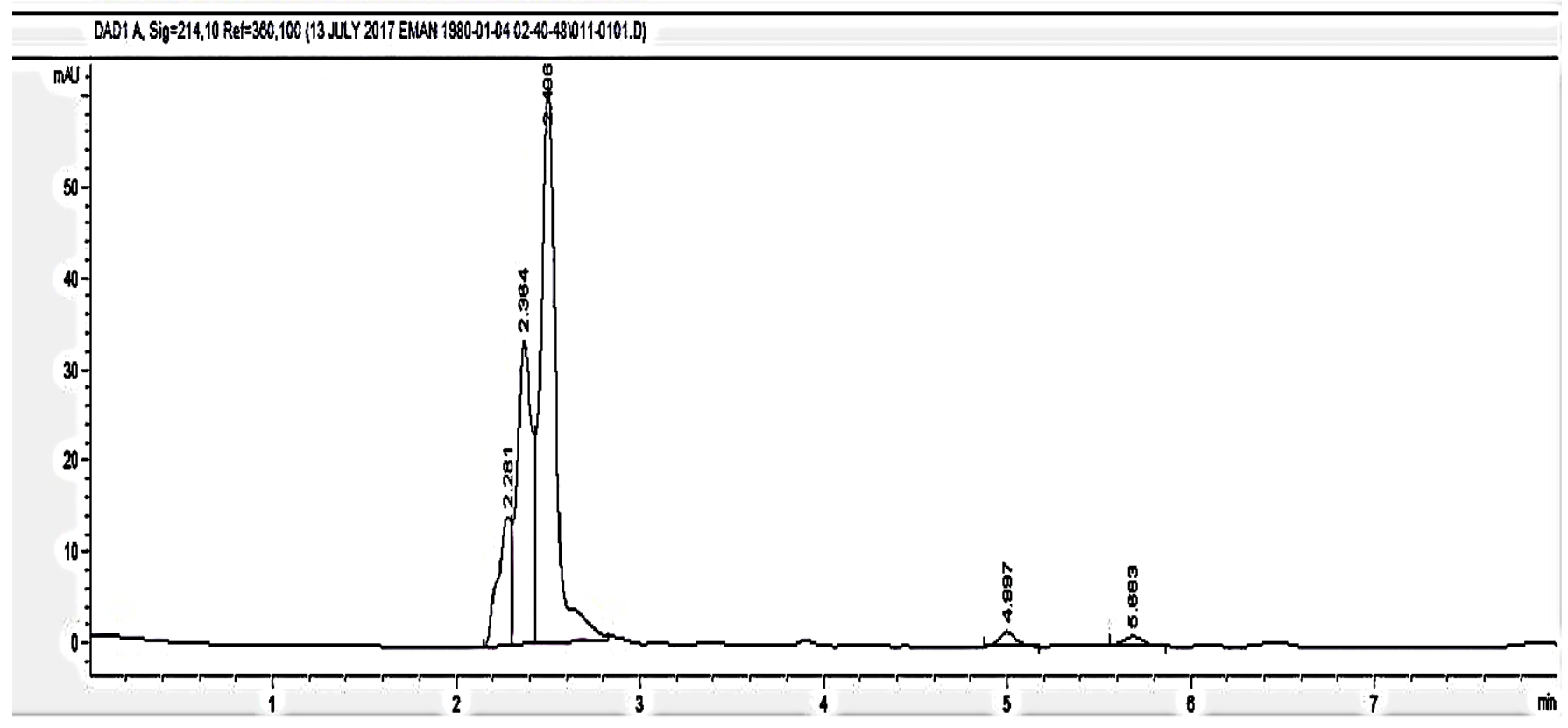

Fig. 2. Chromatogram of blank plasma sample.

times for the three drugs, Clopidogrel bisulfate appears after $10 \mathrm{~min}$. So, a combination of acetonitrile: phosphate buffer at ratio $70-30$ was found to be the ideal mobile phase for separation in this method as the retention time decreased to less than 7 min (Fig. 1).

\section{Column temperature}

The mobile phase was pumped at different column oven temperatures in the range of $25-35^{\circ} \mathrm{C}$. Peak shapes were improved with increasing temperature without affecting resolution and peak areas. So, $33{ }^{\circ} \mathrm{C}$ was found to be the optimum temperature for the separation of the cited drugs.

\section{Flow rate}

The effect of flow rate on the separation was studied to improve the resolution of the eluted peaks. The flow rate was changed over the range of $0.8-1.2 \mathrm{~mL} / \mathrm{min}$. By beginning with the flow rate of $0.8 \mathrm{~mL} / \mathrm{min}$, the total run time was exceeding $10 \mathrm{~min}$ due to increasing the retention times of the three drugs. So, we increase the flow rate gradually in order to decease the total run time until reach the flow rate of $1.2 \mathrm{~mL} / \mathrm{min}$ where, the plasma peak slightly overlapped with the first eluting drug, VAL. So, we decrease the flow rate again to $1.1 \mathrm{~mL} / \mathrm{min}$ to ensure optimal and complete separation between the plasma peak and the three drugs.

\section{Choice of appropriate wavelength}

The three drugs showed main absorption peaks at 210, 214, 240, 255 and $270 \mathrm{~nm}$ but showed maximum absorbance at $214 \mathrm{~nm}$ so, setting the UV detector at $214 \mathrm{~nm}$, permitting the determination of the three drugs at the same time.

\section{Method validation}

\section{Linearity, detection and quantitation limits}

Linear calibration curves representing the relation between the concentrations of drugs versus the peak areas were obtained in the range of $2.5-100 \mu \mathrm{g} / \mathrm{mL}$ for both VAL and CGB and $5-100 \mu \mathrm{g} / \mathrm{mL}$ for FEN. Linear regression equations were obtained and correlation coefficient, slope and intercept were calculated. Results are listed in Table 1.

\section{Accuracy}

Accuracy of the measurements of the suggested method was determined using the calibration standards of the cited drugs. Mean recovery values of $98.89,99.90$ and $101.06 \%$ were obtained for 


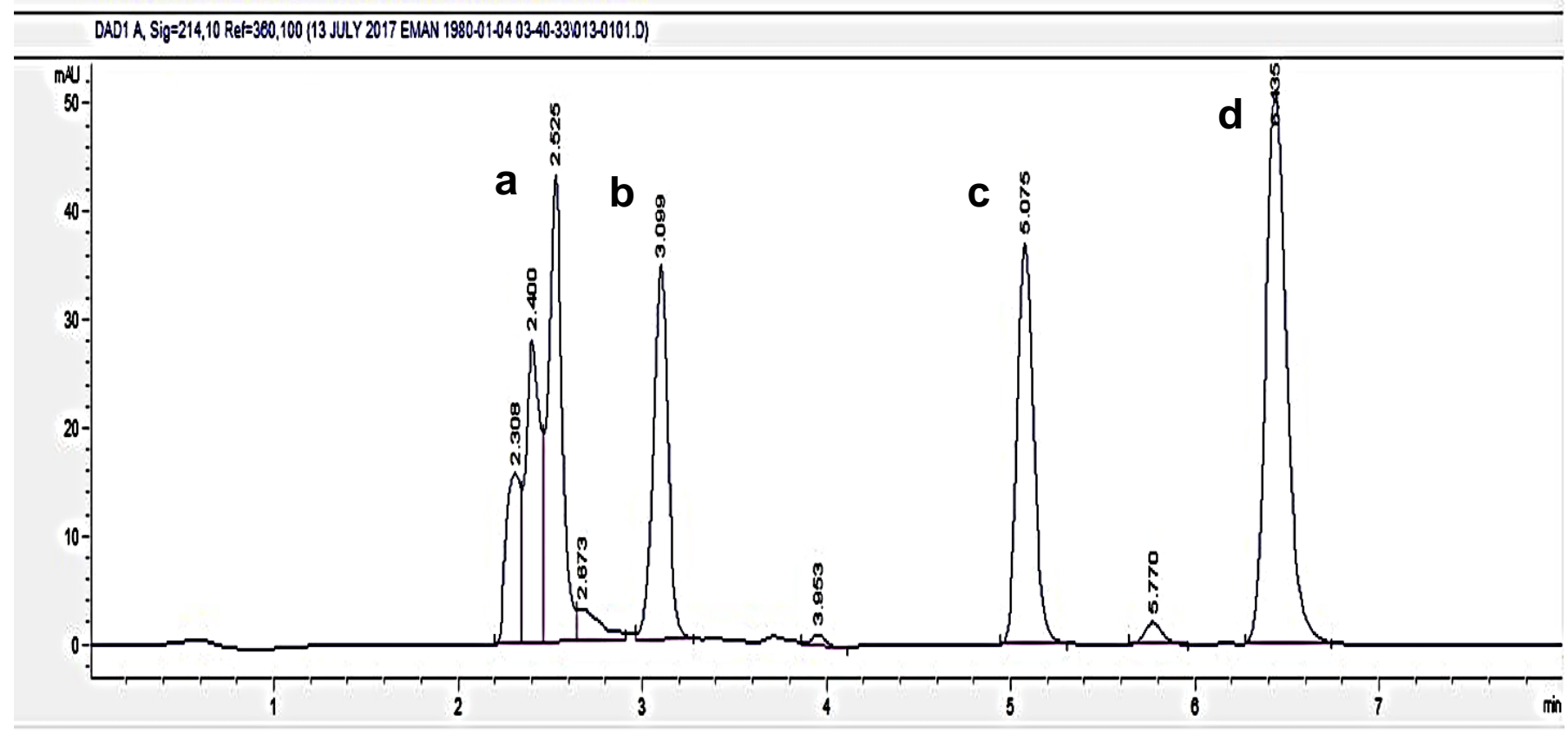

Fig. 3. Chromatogram for (a): Blank plasma (b): VAL $(5 \mu \mathrm{g} / \mathrm{mL})$, CGB $(15 \mu \mathrm{g} / \mathrm{mL})$ and FEN $(20 \mu \mathrm{g} / \mathrm{mL})$ in spiked human plasma.

VAL, CGB and FEN, respectively, indicating high accuracy of the method. Results are listed in the Table 2.

\section{Precision}

The relative standard deviations (RSD) of intra-day assay of the cited drugs were ranged from 0.19 to $2.47 \%$ and for the inter-day assay was from 0.15 to $2.04 \%$. So, the values for RSD were not exceeding $2.5 \%$ which revealed that the precision of the suggested method is very high. The results are listed in Table 3.

\section{Specificity}

Specificity is the ability of the analytical proposed method to discriminate between target analytes and other components that may be present such as excipients, additives or endogenous plasma fluid components. Fig. 2 and 3 show the great specificity of the proposed method. Specificity of the proposed HPLC method was evaluated by its successful application to determine the cited drugs in their tablets with mean recovery of $98.29 \%, 99.57 \%$ and $101.08 \%$ for Tareg ${ }^{\circledR}$ tab, Clopex ${ }^{\circledR}$ tab and Lipanthyl supra ${ }^{\circledR}$ tab, respectively (Table 4 ).

Table 4. Determination of cited drugs in their pharmaceutical preparations using the proposed HPLC method.

\begin{tabular}{|c|c|c|c|c|c|c|c|c|c|}
\hline \multirow{2}{*}{ Sample } & \multicolumn{3}{|c|}{ Tareg® Tablet (VAL) } & \multicolumn{3}{|c|}{ Clopex ${ }^{\circledR}$ Tablet (CGB) } & \multicolumn{3}{|c|}{ Lipanthyl supra ${ }^{\circledR}$ Tablet (FEN) } \\
\hline & $\begin{array}{l}\text { Taken } \\
{[\mu \mathrm{g} / \mathrm{mL}]}\end{array}$ & $\begin{array}{l}\text { Found } \\
{[\mu \mathrm{g} / \mathrm{mL}]}\end{array}$ & $\begin{array}{l}\text { Recovery } \\
{[\%]}\end{array}$ & $\begin{array}{l}\text { Taken } \\
{[\mu \mathrm{g} / \mathrm{mL}]}\end{array}$ & $\begin{array}{l}\text { Found } \\
{[\mu \mathrm{g} / \mathrm{mL}]}\end{array}$ & $\begin{array}{l}\text { Recovery } \\
{[\%]}\end{array}$ & $\begin{array}{l}\text { Taken } \\
{[\mu \mathrm{g} / \mathrm{mL}]}\end{array}$ & $\begin{array}{l}\text { Found } \\
{[\mu \mathrm{g} / \mathrm{mL}]}\end{array}$ & $\begin{array}{l}\text { Recovery } \\
{[\%]}\end{array}$ \\
\hline 1 & 100 & 99.31 & 99.31 & 100 & 99.89 & 99.89 & 100 & 100.42 & 100.42 \\
\hline 2 & 70 & 68.52 & 97.88 & 70 & 70.28 & 100.39 & 70 & 71.07 & 101.52 \\
\hline 3 & 50 & 48.84 & 97.68 & 50 & 50.17 & 100.34 & 50 & 51.13 & 102.26 \\
\hline 4 & & & & 10 & 9.77 & 97.67 & 20 & 20.30 & 100.13 \\
\hline Mean & & & 98.29 & & & 99.58 & & & 100.98 \\
\hline SD & & & 0.89 & & & 1.29 & & & 0.72 \\
\hline RSD & & & 0.90 & & & 1.30 & & & 0.71 \\
\hline
\end{tabular}


Table 5. Determination of cited drugs in spiked human plasma.

\begin{tabular}{|c|c|c|c|c|c|c|c|c|c|}
\hline \multirow[b]{2}{*}{ Sample } & \multirow[b]{2}{*}{$\begin{array}{l}\text { Taken } \\
{[\mu \mathrm{g} / \mathrm{mL}]}\end{array}$} & \multicolumn{2}{|l|}{ VAL } & \multirow[b]{2}{*}{$\begin{array}{l}\text { Taken } \\
{[\mu \mathrm{g} / \mathrm{mL}]}\end{array}$} & \multicolumn{2}{|l|}{ CGB } & \multicolumn{3}{|l|}{ FEN } \\
\hline & & $\begin{array}{l}\text { Found } \\
{[\mu \mathrm{g} / \mathrm{mL}]}\end{array}$ & $\begin{array}{l}\text { Recovery } \\
{[\%]}\end{array}$ & & $\begin{array}{l}\text { Found } \\
{[\mu \mathrm{g} / \mathrm{mL}]}\end{array}$ & $\begin{array}{l}\text { Recovery } \\
\text { [\%] }\end{array}$ & $\begin{array}{l}\text { Taken } \\
{[\mu \mathrm{g} / \mathrm{mL}]}\end{array}$ & $\begin{array}{l}\text { Found } \\
{[\mu \mathrm{g} / \mathrm{mL}]}\end{array}$ & $\begin{array}{l}\text { Recovery } \\
{[\%]}\end{array}$ \\
\hline 1 & 4.0 & 3.60 & 76.49 & 7 & 6.49 & 92.67 & 5 & 5.12 & 102.47 \\
\hline 2 & 5.0 & 3.82 & 76.53 & 9 & 7.96 & 88.40 & 8 & 8.16 & 101.98 \\
\hline 3 & 6.0 & 4.43 & 73.85 & 10 & 9.60 & 90.61 & 10 & 9.86 & 98.65 \\
\hline \multirow[t]{2}{*}{4} & 6.5 & 4.85 & 74.67 & 15 & 13.19 & 87.97 & 20 & 18.56 & 92.83 \\
\hline & & & & & & & 24 & 21.27 & 88.64 \\
\hline Mean & & & 75.38 & & & 89.91 & & & 96.92 \\
\hline SD & & & 1.34 & & & 2.17 & & & 6.20 \\
\hline RSD & & & 1.78 & & & 2.41 & & & 6.20 \\
\hline
\end{tabular}

Also, specificity of the proposed HPLC method was assessed by its successful application to determine drugs in spiked plasma samples with excellent extraction recoveries (74 \% - $102 \%)$ indicating that there was no interference from endogenous plasma components. Results are listed in Table 5.

\section{Robustness}

The method proved to be robust for the minor variations in the method parameters but in case of increasing these small variation as in case of flow rate $(1.05,1.1$ and $1.15 \mathrm{~mL} / \mathrm{min})$, this changes had influence on both peak area and retention time. The results are listed in Table 6.

\section{System suitability}

System suitability test parameters; column efficiency (number of theoretical plates, $\mathrm{N}$ ), tailing factor $(\mathrm{T})$, retention factor $(k)$, selectivity (a) and resolution (Rs) were used to verify that the reproducibility and the resolution of the system were adequate for the analysis to be done (Table 7).

\section{Analytical applications}

The statistical comparison of the results obtained showed that student's $t$-test and $F$-test (at $95 \%$ confidence level) values are less than the tabulated ones, which showed that there is no significant difference between the proposed and reported methods. Results are listed in Table 8. In Addition, the suggested method was applied to analyze drugs in spiked human plasma by simple protein precipitation procedure with acetonitrile: methanol mixture $(1: 1)$ followed by centrifugation and direct injection of the clear supernatant containing the cited drugs and analysis directly by the chromatographic system. Excellent extraction recoveries were obtained in Table 5.

Table 6. Robustness of the proposed method applied on concentration $(50 \mu \mathrm{g} / \mathrm{mL}$ for all substances).

\begin{tabular}{|c|c|c|c|c|c|c|}
\hline \multirow{2}{*}{ Parameter affected } & \multicolumn{3}{|c|}{ Peak area } & \multicolumn{3}{|c|}{ Retention time } \\
\hline & VAL & CGB & FEN & VAL & CGB & FEN \\
\hline Flow rate $(1.10,1.09$ and $1.11 \mathrm{~mL} / \mathrm{min})$ & 0.195 & 0.956 & 0.402 & 1.725 & 2.393 & 2.754 \\
\hline RSD of the affected parameter & & & & & & \\
\hline Flow rate $(1.10,1.05$ and $1.15 \mathrm{~mL} / \mathrm{min})$ & 4.700 & 4.773 & 4.651 & 4.003 & 4.084 & 4.046 \\
\hline RSD of the affected parameter & & & & & & \\
\hline Acetonitrile content $(70.0,70.5$ and $69.5 \%)$ & 0.723 & 0.325 & 0.630 & 1.236 & 0.604 & 0.957 \\
\hline RSD of the affected parameter & & & & & & \\
\hline
\end{tabular}

\section{Conclusions}

The presented HPLC method is simple, precise and can be used by every drug laboratory. This new procedure is very important as these drugs are commonly used as combinations for patients after stroke recovery. Also the small sample plasma volume $(0.5 \mathrm{~mL})$, simple steps for precipitation 
Table 7. Analytical parameters for system suitability test of HPLC method.

\begin{tabular}{lcrc}
\hline Parameters & VAL & CGB & FEN \\
\hline Rs (Resolution) & 2.40 & 12.20 & 7.47 \\
a (Selectivity factor) & 1.18 & 1.78 & 1.35 \\
k (Retention factor) & 1.61 & 2.87 & 3.88 \\
T (Asymmetry or tailing & 0.63 & 0.80 & 0.82 \\
factor) & & & \\
N (column efficiency) & 14103 & 16541 & 16851 \\
$\begin{array}{l}\text { Height equivalent theore- } \\
\text { tical plates (HETP) [mm] }\end{array}$ & 0.018 & 0.015 & 0.015 \\
\hline
\end{tabular}

of plasma proteins, good extraction recovery from plasma, and short run-time (less than $7 \mathrm{~min}$ ) are additional advantages of this method.

Finally, the method was applied to the analysis of both drugs in raw materials, spiked human plasma and tablets dosage forms and can be used for routine laboratories analysis and quality control purposes for pharmaceutical companies and are very beneficial for toxicological and drug interaction studies.

Table 8. Determination of the studied drugs in their tablets dosage forms using the proposed method compared to reference methods.

\begin{tabular}{|c|c|c|c|c|c|c|}
\hline \multirow[b]{2}{*}{ Parameters } & \multicolumn{2}{|c|}{ Tareg ${ }^{\circledR}$ Tablet } & \multicolumn{2}{|c|}{ Clopex ${ }^{\circledR}$ Tablet } & \multicolumn{2}{|c|}{ Lipanthyl supra ${ }^{\circledR}$ Tablet } \\
\hline & $\begin{array}{l}\text { Reference } \\
\text { method }^{a}\end{array}$ & $\begin{array}{l}\text { Proposed } \\
\text { method }\end{array}$ & $\begin{array}{l}\text { Reference } \\
\text { method }^{b}\end{array}$ & $\begin{array}{l}\text { Proposed } \\
\text { method }\end{array}$ & $\begin{array}{l}\text { Reference } \\
\text { method }^{c}\end{array}$ & Proposed method \\
\hline $\mathbf{N}$ & 4 & 3 & 3 & 4 & 5 & 4 \\
\hline Mean Recovery & 99.440 & 98.290 & 99.100 & 99.580 & 100.260 & 101.080 \\
\hline Variance & 0.227 & 0.784 & 0.402 & 1.670 & 0.034 & 0.980 \\
\hline \pm S.D. & 0.465 & 0.886 & 1.091 & 1.290 & 0.185 & 0.989 \\
\hline \pm R.S.D. & 0.468 & 0.901 & 1.100 & 1.300 & 0.185 & 0.979 \\
\hline Student- $t$ & & $2.254(2.5$ & & $0.583(2.5$ & & $1.854(2.365) *$ \\
\hline$F$-test & & $3.068(5.1$ & & $4.154(9.5$ & & $1.651(5.41) *$ \\
\hline
\end{tabular}

${ }^{a}$ Gupta et al. (2010a)

$\boldsymbol{b}$ The British Pharmacopoeia (2017)

${ }^{c}$ Gupta et al. (2010b)

\section{References}

El-Gizawy SM, Abdelmageed OH, Omar MA, Duryea SM, Abdel-Megied AM (2012) Development and validation of HPLC method for simultaneous determination of amlodipine, valsartan, hydrochlorothiazide in dosage form and spiked human plasma. Am. J. Analyt. Chem. 3: 422-430.

Gupta KR, Wadodkar AR., Wadodkar SG (2010a) UVSpectrophotometric methods for estimation of valsartan in bulk and tablet dosage form. Int. J. Chemtech. Res. 2: 985-989.

Gupta KR, Askarkar SS, Rathod PR, Wadodkar SG (2010b) Validated spectrophotometric determination of Fenofibrate in formulation. Pharm. Sin. 1: 173-178.

Gurupadayya BM, Sam S (2014) Bio-analytical determination of Clopidogrel bisulfate and pantoprazole by RP-HPIC method in rat plasma: Application to drug interaction study. Asian J. Pharm. Clin. Res. 7: 10-13.

Gu Q, Burt VL, Dillon CF, Yoon S. (2012) Trends in antihypertensive medication use and blood pressure control among United States adults with hypertension: the National Health and Nutrition Examination Survey, 2001 to 2010. Circulation 126: 2105-2114.

Hall MJ, Levant S, Defrances CJ (2012) Hospitalization for stroke in US hospitals, 1989-2009. NCHS Data Brief
95: $1-8$.

International Conference On Harmonization. Validation of Analytical Procedures: Text and Methodology, 2005.

Jain N, Raghuwanshi R, Jain D (2008) Development and Validation of RP-HPLC method for simultaneous estimation of atorvastatin calcium and fenofibrate in tablet dosage forms. Indian J. Pharm. Sci. 70: 263265.

Khaleel N, Abdul Rahaman SK (2016) Validated stability indicating RP-HPLC method for simultaneous determination of atorvastatin, Fenofibrate and folic acid in bulk and pharmaceutical dosage form. Pharm. Lett. 8: 13-32.

Kernan WN, Ovbiagele B, Black HR (2014) Guidelines for the prevention of stroke in patients with stroke and transient ischemic attack: a guideline for healthcare professionals from the American Heart Association/American Stroke Association. Stroke 45: 2160-2236.

Lackland DT, Roccella EJ, Deutsch AF (2014) Factors influencing the decline in stroke mortality: a statement from the American Heart Association/American Stroke Association. Stroke 45: 315-353.

Londhe SV, Deshmukh RS, Mulgund SV, Jain KS (2011) Development and validation of a Reversed-phase HPLC method for simultaneous determination of aspirin, 
atorvastatin calcium and Clopidogrel bisulfate in capsules. Indian J. Pharm. Sci. 73: 23-29.

Ovbiagele B (2011) National sex-specific trends in hospitalbased stroke rates. J. Stroke Cerebrovascular Dis. 20: 537-540.

Rosengren A, Giang KW, Lappas G, Jern C, Toren K, Bjorck $\mathrm{L}$ (2013) Twenty-four-year trends in the incidence of ischemic stroke in Sweden from 1987 to 2010. Stroke 44: 2388-2393.

Sahu PK, Murthy Pyla SR, Srinivas K, Swain S (2016) Simultaneous RP-HPLC method development and validation of atorvastatin, ezetimibe and fenofibrate. Pharmaceut. Reg. Affairs 5: 1-6.

Shrivastava PK, Basniwal PK, Jain D, Shrivastava SK (2008) Concurrent estimation of Clopidogrel bisulfate and aspirin in tablets by validated RP-HPLC method. Indian
J. Pharm. Sci. 70: 667-669.

Sweetman S (2009) Martindale, The complete drug reference, $36^{\text {th }}$ edition, Pharmaceutical Press, cop., London, UK, $3694 \mathrm{p}$.

Tian DF, Tian XL, Tian T, Wang ZY, Mo FK (2008) Simultaneous determination of valsartan and hydrochlorothiazide in tablets by RP-HPLC. Indian J. Pharm. Sci. 70: 372-374.

The British Pharmacopoeia. London, UK, Her Majesty's Stationary Office, 2017.

The United States Pharmacopoeia, Vol. XXIV, Washington, 2007.

Wang Y, Rudd AG, Wolfe CD (2013) Trends and survival between ethnic groups after stroke: the South London Stroke Register. Stroke 44: 380-387. 